\title{
Teachers' and Learners' Perceptions toward Using Social Media for Developing Oral Proficiency
}

\author{
Ehsan Namaziandost \\ Department of English, Faculty of Humanities, Shahrekord Branch, Islamic Azad University, Shahrekord, Iran \\ Mehdi Nasri \\ Department of English, Faculty of Humanities, Shahrekord Branch, Islamic Azad University, Shahrekord, Iran \\ Mohammad Hossein Keshmirshekan \\ Department of English, Faculty of humanities, Yazd University, Yazd, Iran
}

\begin{abstract}
Social media is one of the most important sources of communication in this technological age which enables the people to share their views and thoughts with other friends, relatives, colleagues, class fellows, and teachers without any problem of distance. Therefore, the main purpose of this study was to highlight the role of social media, and to compare the views of teachers and learners regarding the use of various social media sources in English language learning proficiency at university level. The data for this descriptive study was collected through self-made questionnaire. The participants of this study were two hundred (200) university level English learners and teachers (100 learners and 100 teachers). The outcome of the study showed that the frequent usage of Social media by EFL students as well as teachers constitutes a significant impact on both users. It has also reflected the teachers' readiness to integrate Social media in EFL context by means of a convenient pedagogy. The result of this study showed that both teachers and learners had positive attitude toward using social media in oral proficiency at university level.
\end{abstract}

Index Terms—social media, speaking skill, EFL students, EFL teachers

\section{INTRODUCTION}

Internet based life are PC intervened instrument that enable individuals to make, offer or trade data, thoughts, and pictures/recordings with different companions or relatives. Web-based social networking assumes a significant job in this present aggressive and innovative period. There are different devices of Social Media which are generally utilized among the college level develop students like Facebook, WhatsApp, Twitter, and LinkedIn and so forth. It is obvious from the consequences of past research examines and handy perceptions of different dynamic clients of Facebook, WhatsApp and different instruments of internet-based life that it positively affects the English language learning capability at college level. The vast majority of the youthful learners at college level utilize different internet-based life instrument for social association, ubiquity, social relations, and English language learning purposes. Diverse research thinks about ahead of time nations have unmistakably featured the significance of Social Media sources like (Facebook, Twitter, Flicker, LinkedIn, WhatsApp, and Skype). Internet based life assumes a critical job not just in one single ability or competency of English language however assumes an extraordinary job in the four fundamental aptitudes of language for example Tuning in, Speaking, Reading, and Writing and furthermore builds up the jargon and sentence structure competency of English language in a legitimate way. The most significant part of web-based life sources in English language learning is that it makes the EFL students independent to do the act of tuning in, speaking, perusing, and composing at home, in guesthouse, on street or in a shop with no trouble.

Integration of innovation, utilization of different online web-based social networking sources for example (Facebook, Twitter, Flicker, LinkedIn, WhatsApp and Skype) and considering creative showing techniques and learning approaches in recent years invigorated instructors to educate in a considerably more agreeable, persuading and functional learning condition. It is because of this reality students' advantage is restricted to those headings which are available for them without a lot of dedicated and battle like before to peruse diverse course readings in libraries. Presently days the old conventional paper-based techniques for training learning procedure have moved to electronic and advanced innovation to a more noteworthy degree. The vigorous students need to upgrade significant learning while at the same time utilizing new procedures and afterward relate it their genuine lives encounters for instance different internet based life sources like Facebook, Twitter, Flicker, LinkedIn, WhatsApp, and Skype in light of the fact that it encourages Collaboration, cooperation, peer appraisal and furnish reasonable condition of offering data to their group colleagues and companions in the most straightforward conceivable way (Namaziandost \& Nasri, 2019; Namaziandost, Rahimi Esfahani, \& Ahmadi, 2019). 
The significance of this study then is to help EFL learners find the right environment to speak and improve their speaking skills by means of Social media. The work covers also, a variety of creative solutions and ideas concerning using ICTs to enhance the learners speaking proficiency (Namaziandost \& Nasri, 2019).

Those learners who are utilizing Social Media and they approach it then they may share subject related data to one another effectively and they can get input from their group colleagues and particularly from those educators who utilize internet-based life sources like Facebook. It is fundamentally learners-focused methodology and helpful for them since they can utilize their very own insight, get new learning, get assistance to express their very own thoughts decisively with their associated educators and instructors.

Concerning the fundamental issue of this examination, it is indispensably essential to make reference to that the speaking expertise of any language is critically vital on the grounds that it fills the need of correspondence which is this language utilizing by all individuals around the globe to share their thoughts and impart by means of a language discourse, particularly, English language discourse which is the most valuable one on the planet. EFL students in Iran are one of those clients of English as an unknown language (Namaziandost and Ahmadi, 2019). They are looking all an opportunity to improve their speaking expertise since English as an unknown language in Algeria is primarily educated as far as language structure and structures. Along these lines, less consideration is payed to the speaking expertise. Along these lines, this need to improve the speaking ability for Iranian EFL students has prompted the utilization of better approaches for innovation so as to stay aware of the occasions. As an issue certainty, they utilize Social media to speak with various individuals around the globe utilizing English as a worldwide language of correspondence. Beginning starting here we have to know whether Social Media effectsly affect EFL students speaking expertise.

Therefore, this study is designed to find answers to two main research questions:

RQ1. What are the students' perceptions toward using social media?

RQ2. What are the students' perceptions toward using social media?

\section{LITERATURE REVIEW}

\section{Introduction}

Life is extremely plain and simple by utilizing new innovation. One of the incredible advancements that has changed the world is the Internet and its capacity in giving on the web correspondence. Individuals utilize the online correspondence in doing some normal day by day life exercises like showcasing, interfacing with companions and perusing news. Electronic correspondence and PCs are things individuals or learners need to manage each day. The world is locked in with associations. We are connected to the virtual world in which we invest the greater part of our energy. We are connected to one another by conventional and social associations, for example, relatives just as by physical and situational conditions. We are likewise connected to one another by harmonies, joint encounters and similar perspectives (Nasri, Biria, \& Karimi, 2018).

The mind-boggling spread of Social media among students and even instructors substantiated itself as an effective device to training. Thus, most educators accept that the primary point behind learning a language is to talk it easily and precisely which implies that understanding a language ought not really build the presumption that he/she knows the language (Namaziandost, Nasri, \& Rahimi Esfahani, 2019; Nasri \& Biria, 2017). The student ought to rather achieve an incredible degree of capability in the four language abilities including speaking. In any case, speaking an unknown language isn't a simple errand, and it is unquestionably not as simple as speaking native language. As an answer, numerous researchers accept that the proper utilize and the fruitful reconciliation of ICTs and web-based life in the study hall can lessen the hindrances that forestall EFL students from the dominance of the speaking aptitude.

\section{A. Speaking Skill}

Speaking is a key utilized between individuals to impart in the social setting. Additionally, Speaking is "the way toward structure and sharing importance using verbal and non-verbal images, in an assortment of settings" (Chaney, 1998, p. 13). Brown (1994) and Burns and Joyce (1997) characterize Speaking as a responsive procedure of an organized implying that incorporates accepting and creating and sharing data. In Applied etymological speaking has a lot of depictions; speaking as a social and circumstance-based action and speaking as a communication, (Azadi, Biria, \& Nasri, 2018; Thornbory, 2005). Every one of these viewpoints consider addressing be an entire side of student's day by day lives in accepting and creating discourse.

Speaking is a significant language aptitude for students and instructors. Bygate (2002) Sees it as a complex, and staggered aptitude; the intricacy part is clarified by the way that the utilization of speakers' information of the language and enact their capacity is important to do this under genuine circumstances.

Speaking has a critical influence in outside/second language educating learning. It has involved a noteworthy and fragile position entirely through the historical backdrop of language educating. Regardless of its significance, training speaking has been underestimated and it is simply over the most recent two decades that has picked up its entitlement to be an independent4 part of instructing (Hosseini, Nasri, \& Afghari, 2017). Speaking at that point isn't needy just on articulating words. English instructors in this way, committed vital time to speaking as being basic in encouraging the upgrade of English learners' capability. 
Speaking, yet is an expertise which merits consideration, the students frequently should probably talk with trust so as to do huge numbers of their most essential exchanges. It is the aptitude by which they are most every now and again judged and through which they may accept or lose open doors throughout everyday life (Namaziandost, Abdi Saray, \& Rahimi Esfahani, 2018). It is the vehicle of social solidarity, of social positioning, of expert headway and of business. Maybe at that point, the educating of speaking merits more idea.

\section{B. Issues of the Oral Production Class in the English Department}

One of the real duties of any instructor working with English Language Learners (ELLs) is to empower them to convey adequately through oral language. Instructors worried about training the verbally expressed language for the most part banter completely around one inquiry: for what reason is it unreasonably hard for students to learn oral articulation? To an enormous degree, it is on the grounds that the present oral generation class is instructor focused, in spite of the different endeavors educators make to connect with students in talks and inspire them to talk, the measure of addresses learners has are as yet not adequate. Also, the Oral language that learners learn at the homeroom does not help in improving their open capabilities which are for the most part required, all things considered, circumstances. Additionally, Baker and Westrup (2003, p.5) express that: "an learner who can communicate in English well may have more prominent possibility for further instruction, discovering work and picking up advancement".

In a similar line of idea, speaking gives off an impression of being a troublesome ability to create in the EFL classes since learners not just should be decidedly ready in English aptitudes, they need likewise to utilize them to assemble social connections that enable them to cooperate with one another. A contention that supports this view is found in Gutierrez (2005, p.3) proclamation he asserts that: "students regularly should almost certainly speak7 with trust so as to complete a significant number of their most fundamental exchanges. It is the ability by which they are most much of the time judged, and by which they make or lose companions". Notwithstanding what has been referenced before, numerous different components keep students from arriving at oral articulation capability in class a large portion of which are mental, for example; nervousness and restraint. There are numerous strategies that ought to be settled on by language instructors to improve students' capability in Oral Expression module among which gathering work, pretend and discourses which urge learners to take informative activities (Namaziandost, Saberi Dehkordi, \& Shafiee, 2019). Besides, students can't be successful in tomorrow's reality on the off chance that they are prepared in yesterday's ability which implies that the learner who use innovation in pretty much every undertaking of his day by day life should utilize innovation also improve his speaking expertise.

\section{Technology and Learning Tools in the EFL Classroom}

Above all else, the most recent two decades have seen fast blasts of data which lead to a pressing need to adapt to the progressing logical increasing speed in all fields. Data upset, which yielded the web, is the most significant mechanical achievement to date. Web empowers individuals to drop separations, abbreviate time, and make the world increasingly like a little electronic screen (Al Musa, 2002; Namaziandost, Abedi, \& Nasri, 2019). Likewise, instruction is required to address the issues of this developing logical increasing speed. To put it another way, instruction points and goals in the Third World nations ought to be changed to meet the period's factors, pointing not exclusively to help learners in the subjective area, yet in addition center around their needs to achieve the abilities, limits, and self - dependence to associate with the time's factors and assemble another life dependent on power, not reliance on others ( $\mathrm{Al} \mathrm{Musa} \mathrm{\&} \mathrm{Al}$ Mubarak, 2005; Namaziandost, Abedi, \& Nasri, 2019).

Instruction needs to furnish learners with the required devices and aptitudes that make them equipped for managing these new necessities adequately. Consequently, including innovation as an objective in itself in the instructive worldview is never again a benefit; despite what might be expected, it is a critical need (Aziz, Shamim, Aziz, \& Avais, 2013). With the expanding dependence on innovation and the requirement for computerized capability, it is normal that the utilization of online innovation to work with second language obtaining is a characteristic side-effect of the changing essence of the instructive world. Confirmations have demonstrated that learners who lead their learning on the web are superior to learners who work in conventional settings for the learning of a subsequent language, as far as their degrees of uneasiness and their requirement for hole mindfulness in their language aptitudes (Akinola, 2015; Pichette, 2009). Studies have additionally demonstrated that the utilization of advances in encouraging languages have an expanded preferred position on the improvement of language structure, jargon, perusing, composing, elocution, tuning in, and speaking skills (Haigh, 2010; Levy, 2009; Namaziandost \& Shafiee, 2018).

\section{Social Media}

The importance of the term 'Web based life' can be gotten from two words that are 'social' and 'Systems'. The main term is 'Social' which means associated with society and the manner in which it is sorted out, in which they meet and invest energy with other individuals. The subsequent one is Networks which implies: a gathering of at least two PC frameworks connected together (Eren, 2012; Beal, 2015; Namaziandost, Sabzevari, \& Hashemifardnia, 2018).

Online networking is a present marvel that incorporates both electronic correspondence with Internet clients through sites and collaboration with others by means of mobile phones. It is evident that training industry worldwide is amidst an upset brought about by the advancing advances, for example, the web 2.0 and the approach of web 3.0 enabling learners to make content, trade thoughts and offer learning. To such an extent that over the most recent couple of years 
there has been broad exchange and warmed discussion investigating web-based life in diary articles and meetings. Quite a bit of this discourse has concentrated on building up a clearer comprehension of the capacities of such innovation as another stage for upgrading students ${ }^{e e}$ autonomous learning and the amount Social media has yielded as scholarly accomplishment and whether it could be utilized as new academic devices outside or even inside the study hall. Simultaneously, the pervasive nearness of web-based social networking has pulled in scientists to examine both positive perspectives and worries of utilizing such instruments in different settings offering new and different methods for utilizing PCs or/and cell phones (Hashemifardnia, Namaziandost, \& Rahimi Esfahani, 2018; Paliktzoglou \& Suhonen, 2014).

As training organizations are grasping web-based social networking there is a need to streamline the constructive outcome of such advancements to carry them into teaching method to make guidance and learning dynamic and relevant to the digital condition of the new thousand years. As of late, increasingly more training foundations are making a nearness in Social media, for example, Blogs, Twitter, YouTube, Facebook to make powerful ways for the foundation of synergistic and intelligent web-based learning framework. Along these lines, innovation driven culture is highlighting conspicuously in every educational action. Henceforth, the focal point of learning and guidance should be seen from a more up to date viewpoint "without social occasion learners and instructors in the17 same physical space" (Aloraini, 2012; Maney, 2009).

Internet based life with its different sorts could be considered as a cure as these materials can possibly pull in the learners by being adaptable, engaging, and intuitive and give an astounding opportunity to students to convey what needs be in a fearless manner. For sure, the utilization of Social media as a device to improve learners' tuning in and speaking/informative aptitudes would locate an eager welcome from the students' part as it goes hand to hand with their interests (Gibbins \& Greenhow, 2016; Hashemifardnia, Namaziandost, \& Sepehri, 2018). As Social media have entered so profoundly in our lives, it is immensely essential to break down the sorts and nature of every mean.

\section{METHODOLOGY}

\section{A. The Population}

The present research work is a survey study involving both EFL teachers $(\mathrm{N}=80)$ and students $(\mathrm{N}=120)$ at Islamic Azad universities of Iran. A survey design is defined by (Dana Lynn Driscoll, 2011) as a study "where you can gather information about people's beliefs or behaviors; the information you collect is not first-hand (like an observation) but rather self-reported data" Consequently, opting for a survey design to figure out the influence of Social media on EFL learners can be more appropriate especially with combining both qualitative and quantitative approaches; this last will help to seek more reliable and valid results from both teachers and students.

The research was conducted at the department of Foreign Languages (English section) at Islamic Azad universities of Iran. The researcher deals with a sample of population consisting of both EFL teachers $(\mathrm{N}=100)$ and students $(\mathrm{N}=100)$ during the academic year 2018/2019. This research aims at drawing interest from both EFL teachers and learners to make use of Social media as an attempt to raise awareness about its great effects in shaping the students' oral proficiency, and also to spark their interest in learning speaking.

1. Teachers

In the present study, the questionnaire was administrated to one-hundred (100) teachers from the department of English at the Islamic Azad universities of Iran. There has been an underlying reason for making EFL teachers involved in the research population because teachers play an intensive role, on the one hand they can be regarded as direct observers of the phenomenon and can evaluate students' oral proficiency during the course, on the other hand they can simply be engaged in oral discussions with learners through the use of Social media and this will show how Social media influence the students' level of speaking. The teachers taking part in this study hold either the degree of 'Doctorate' or 'Magister' most of them were experienced teachers who taught different modules.

2. Students

The choice of the sample of the students was based on the observation that was done by the researchers, where we observe the WhatsApp, Facebook, and Telegram groups that are created by students of the department of English at the universities of Iran from all the different levels and specialties. In these groups, students are sharing and discussing course-related materials with their classmates. Therefore, the present study took place in the Department of English at Islamic Azad universities of Iran. The participants were 100 students of English randomly selected as a sample population for the present study. They belonged to different levels from First year to master two students. The main aim behind this blend was to gather as much points of view about the use of Social media and examine their attitudes towards them and for a greater extent to derive from learners a variety of creative ideas on how to better use Social media to improve speaking.

\section{B. Research Instruments}

It is often assumed that "the backbone of any survey study is the instrument used for collecting data"(Dornyei \& Ushioda, 2011) therefore, the researcher has opted for the use of two questionnaires one intended for teachers and the other for students, basically the same questions were asked with a slight difference in the style .

Questionnaire 
The essence of any scientific research is the attempt made to find out answers to questions in a systematic manner. Yet, questionnaires in their various kinds are of the most common methods in collecting data in Foreign Language research and have attracted a worldwide interest among researchers. In the same vain Dornyei (2003, p.3) states: "Questionnaires are certainly the most often employed data collection devices in statistical work".

The questionnaire is addressed to EFL students and Teachers aiming at analyzing to which extent Social media impact the students' speaking skill and which strategies can be undertaken in order to integrate Social media in educational institutions such as university. Eight questions were included and different types of questions were used starting from open-ended and close-ended to multiple choice questions.

\section{RESULTS}

\section{A. Analysis of Teachers' Questionnaire}

The questionnaire is addressed to ten EFL teachers. It mainly aims at reporting their ideas concerning the use of Social media among learners and teachers as well. In addition to that, its basic purpose is to show their impressions about how Social media contribute in shaping the students ${ }^{\text {ee }}$ speaking skills. This questionnaire includes eight questions that will be analyzed and presented as shown below.

TABLE I.

TEACHERS' ANSWERS TO THE QUESTIONNAIRE

\begin{tabular}{|c|c|c|c|}
\hline \multicolumn{4}{|c|}{ Question 1. How often do you use Social media? } \\
\hline Frequency of Use & Absolute Frequency & & Percentage \\
\hline Always & 55 & & $55 \%$ \\
\hline Sometimes & 35 & & $35 \%$ \\
\hline Rarely & 5 & & $5 \%$ \\
\hline Never & 5 & & $5 \%$ \\
\hline \multicolumn{4}{|c|}{ Question 2. Have you ever used Social media for educational purposes? If yes, How? } \\
\hline Frequency of Use & Absolute Frequency & & Percentage \\
\hline Yes & 80 & & $80 \%$ \\
\hline No & 20 & & $20 \%$ \\
\hline \multicolumn{4}{|c|}{ Question 3. Do you get in touch with learners through the use of Social media? } \\
\hline $\begin{array}{l}\text { The use of S.N to } \\
\text { communicate with } \\
\text { learners }\end{array}$ & Absolute Frequency & & Percentage \\
\hline Always & 14 & & $14 \%$ \\
\hline Sometimes & 76 & & $76 \%$ \\
\hline Rarely & 3 & & $3 \%$ \\
\hline Never & 7 & & $7 \%$ \\
\hline \multicolumn{4}{|c|}{$\begin{array}{l}\text { Question 4. Among the different types of social media, there are social media that are mostly based on oral communication such as } \\
\text { Skype, WhatsApp or Telegram. As a teacher do you use one of these to get in touch with learners or native speakers? If yes, which } \\
\text { one is your favorite? }\end{array}$} \\
\hline The Social Media & Number & & Percentage \\
\hline Skype & 8 & & $8 \%$ \\
\hline WhatsApp & 51 & & $51 \%$ \\
\hline Telegram & 39 & & $39 \%$ \\
\hline None & 2 & & $2 \%$ \\
\hline \multicolumn{4}{|c|}{ Question 5. Which language is mostly used when using these tools? } \\
\hline The Language Used & Absolute Frequency & & Percentage \\
\hline Mother Tongue & 13 & & $13 \%$ \\
\hline English & 84 & & $85 \%$ \\
\hline Arabic & 2 & & $2 \%$ \\
\hline None of the languages & 1 & & $0 \%$ \\
\hline \multicolumn{4}{|c|}{ Question 6. To what extent can Skype, WhatsApp or Telegram be helpful to students? and why? } \\
\hline The Influence & Absolute Frequency & Percentage & Reasons \\
\hline High & 24 & $24 \%$ & $\begin{array}{l}\text { Because they practice the } \\
\text { language. }\end{array}$ \\
\hline Medium & 72 & $72 \%$ & $\begin{array}{l}\text { Because Social media } \\
\text { represent a motivating } \\
\text { and helpful environment. }\end{array}$ \\
\hline Low & 4 & $4 \%$ & $\begin{array}{l}\text { Because students need } \\
\text { face to face interaction. }\end{array}$ \\
\hline
\end{tabular}

The primary inquiry targets discovering to what degree instructors are connected to Social media and how frequently do they use them. In view of Table 1, The lion's share spoken to by five instructors utilize Social media consistently, while three of them use them here and there and just two educators have never utilized Social media. The subsequent inquiry was intended to decide the quantity of instructors utilizing Social media for instructive purposes. The principle point behind this inquiry is to find how educators utilize Social media to accomplish any instructive objectives. (80\%) of instructors affirm that they utilize Social media for instructive purposes, for example, sharing talks, distributing helpful connections or sending messages to partners or learners, while just a single educator utilized Social media to 
give addresses. The staying (20\%) accept that Social media can all the more likely be utilized for different reasons. The appropriate responses concerning this inquiry uncovered that in spite of the way that most instructors utilize Social media to accomplish instructive objectives, just few of them use them to give addresses or perform oral discussions with students. As to third question, the method of reasoning of this inquiry is to make sense of if educators profit by Social media at the degree of imparting data and thoughts with EFL students. The discoveries of this inquiry uncover that (76\%) of educators now and again utilize Social media to speak with students in issues bound to be identified with training while $(7 \%)$ have never utilized them to speak with students. Being referred to four, knowing which Social media educators lean toward is a definitive objective of such an inquiry. Instructors and even students may have diverse Social media to utilize when they look for oral correspondence in this manner, it is imperative to our examination to know which Social media positions the best among EFL educators. The outcomes demonstrate that WhatsApp is the most utilized Social media among educators with $(51 \%)$ while $(39 \%)$ of them are utilizing Telegram. Instructors have settled on their decisions dependent on various criteria that describe every Social media. Question five is regulated trying to know which language is being utilized by educators when utilizing Social media and furthermore to check whether instructors are utilizing these Social media to contribute in the entire field of training. The outcome signifies the astounding control of English over different languages being used, explore demonstrates that most educators spoke to with $(84 \%)$ utilize English as the fundamental Language in oral correspondence, while Mother Tongue is positioned second with $(13 \%)$ of use. $(1 \%)$ of instructors express that they don't utilize any language and their utilization is altogether latent. To wrap things up, the utilization of Arabic language with just (2\%). Question six is structured trying to know the instructors' perspective about the primary issue of the entire research which is the impact of Social media on the learners speaking expertise; it likewise incorporates an open door for educators to legitimize their assessments. As needs be, the outcomes show that the general number of instructors accept that Social media do affect the learners' degree of speaking. As the outcomes appear, seven instructors estimated the impact at medium level ascribing their decision to the spurring and helping condition that Social media give. What's more, twenty-four instructors guarantee that Social media have a high impact since they speak to a plentiful chance to rehearse the language and in this manner improve the speaking ability. Then again, there is just four educator who goes with the possibility that the impact is low and scarcely existing since Social media don't give up close and personal communication and thusly, the constructive impact is extremely low.

\section{B. Analysis of the Students' Questionnaire}

This questionnaire is mainly designed to diagnose the students' use of Social media and its impact on the students speaking skill. After treatment of the teachers' questionnaire, the present section is devoted to the analysis of the data collected from the students' questionnaire. All 100 students answered this questionnaire for the sake of obtaining as much as various data available. The questionnaire consisted of six questions and each one will be treated separately as follow: 
TABLE II.

STUDENTS' ANSWERS TO THE QUESTIONNAIRE

\begin{tabular}{|c|c|c|}
\hline \multicolumn{3}{|c|}{ Question 1. Do you use Social media? } \\
\hline The use & Absolute Frequency & Percentage \\
\hline Always & 82 & $82 \%$ \\
\hline Sometimes & 16 & $16 \%$ \\
\hline Rarely & 2 & $2 \%$ \\
\hline Never & 0 & $0 \%$ \\
\hline \multicolumn{3}{|c|}{ Question 2. Have you ever used Social mediaing for educational purposes? If yes, How? } \\
\hline The influence & Absolute Frequency & Percentage \\
\hline A lot & 71 & $71 \%$ \\
\hline A little & 27 & $21 \%$ \\
\hline Not at all & 0 & $0 \%$ \\
\hline I don't know & 2 & $2 \%$ \\
\hline \multicolumn{3}{|c|}{$\begin{array}{l}\text { Question 3. Among the different existing Social media there are, those which can be used in oral communication such as Skype } \\
\text { Whats App or Telegram, do you use any of them? If yes which one is your favorite? }\end{array}$} \\
\hline The Social Media & Number & Percentage \\
\hline Skype & 1 & $1 \%$ \\
\hline WhatsApp & 69 & $69 \%$ \\
\hline Telegram & 29 & $29 \%$ \\
\hline None & 1 & $1 \%$ \\
\hline \multicolumn{3}{|c|}{ Question 4. Which language do you use when doing so? } \\
\hline The Language Used & Absolute Frequency & Percentage \\
\hline Mother Tongue & 21 & $21 \%$ \\
\hline English & 78 & $78 \%$ \\
\hline Other languages & 1 & $1 \%$ \\
\hline \multicolumn{3}{|c|}{ Question 5. Have you ever used Social media to talk with native speakers of English around the world? } \\
\hline The use & Number & Percentage \\
\hline Yes & 77 & $77 \%$ \\
\hline No & 33 & $33 \%$ \\
\hline \multicolumn{3}{|c|}{ Question 6. To what extent do you think these types of Social media can help to improve students' speaking skills? } \\
\hline The Influence & Absolute Frequency & Percentage \\
\hline High & 82 & $82 \%$ \\
\hline Medium & 18 & $18 \%$ \\
\hline Low & 0 & $0 \%$ \\
\hline
\end{tabular}

The primary inquiry has been posed for two fundamental reasons the first is to connect with the member in the theme so he/she builds a past learning about what is coming next of inquiries. Furthermore, to realize how far learners are connected to Social media. Most of members (eighty-two) making up (82\%) expressed that they generally utilize Social media, while just sixteen learners making (16\%) expressed that their utilization of Social media isn't a need and in this manner, they use them just now and then. As to second question, it is significant for the analyst to know the learners' point of view about the impact of Social media just on the grounds that they speak to a successful part in the marvel. The outcomes have demonstrated that most learners seventy-two, making up (72\%) accept that Social media do impact a great deal the learners' level, while twenty-seven learners making up (27\%) asserted that the impact is unpretentious and have little impact, other than this, lone two learners did not have an answer. The third inquiry was routed to EFL learners to know which Social media is generally utilized or supported by learners. The appropriate responses concerning this inquiry have uncovered that WhatsApp is the most supported Social media between learners making up $(69 \%)$ of clients, while Telegram involved the second most utilized Social media with twenty-nine learners making up (29\%). Skype then again positioned the third with one client making up (1\%), while just a single learner guaranteed they don't utilize any. Question four is formulated to decide the language that learners for the most part use when utilizing Social media. This inquiry is basic to the exploration work. It demonstrates its essentialness to the extent English is concerned. The examination has shown that seventy-eight learners making up (78 \%) utilize English as the principle language for oral correspondence in Social media while twenty-one learners making up (21\%) pick the Mother tongue. Also, one learner making up (1\%) utilizes different languages. A few learners picked more than one decision which implies that they move from one language to the next as per the speakers' need. Behind inquiry five, the scientist planned to know the degree to which learners of English are utilizing Social media by having oral discussions with local speakers. The outcomes have shown that sixty-seven learners making up $(77 \%)$ have had the chance to address local speakers on the web, while just nine making up (23\%) learners did not experience the experience. By the inquiry 6th, the specialist needed to know EFL learners' frames of mind and thoughts towards the work of Social media in instructive fields to improve speaking ability. Most of learners making up (82\%) imagine that Social media do improve the speaking capability to a high degree, while (18\%) of learners asserted that the improvement is medium since the procedure is at the danger of causing numerous weaknesses.

\section{DiSCUSSION AND CONCLUSION}

As a matter of first importance, it merits saying that educators at the college are aware of the headway and advancement of correspondence and innovation and its presumption to the field of instruction, and what makes this 
genuine is the regular utilization of Social media by instructors who will in general distribute instructive connections and offer information with their learners. In addition, the advantage picked up from Social media is reliant, and contrasts starting with one instructor then onto the next, in the equivalent vain just couple of educators utilize Social media for web-based addressing. Furthermore, WhatsApp and Telegram have very huge prevalence among educators in correlation with other Social media. In this way, their utilization includes for the most part associates and not learners. Moreover, educators put stock in the impact of Social media supporting their point of view with the way that Social media offer the learners the chance to rehearse the language because of the inspiring and accommodating condition it gives. Another key thing to recall is that instructors view Virtual Classroom as an exceptionally fruitful encounter and would upgrade the learner learning and speaking capacities through the discussions directed with local speakers of English. So also, educators do concur that Social media can be utilized at college to improve speaking and tuning in too. The primary test, in any case, lies at the academic procedures that ought to be followed so as to actualize Social media and how they can best be utilized, also the accessibility of vital gear.

The serious utilization of Social media by learners ought not be taken a gander at just as a negative procedure. To put it another way, Social media has turned into a day by day propensity among learners and the incorporation of online discussions in English class ought to give an environment of pleasure just as keep the learner in the correct way towards improving his/her very own abilities. Learners on their part know about the impact of Social media. They use them for different purposes extending from instruction to correspondence and diversion. Fundamentally, if these reasons for existing were accomplished in the objective language (English) the learners' capability in speaking would observer a wonderful advancement. WhatsApp and Telegram have enormous notoriety among learners and this bodes well since Messenger is an extra device and associated with the most utilized Social media everywhere throughout the world that is Facebook. The exploration has uncovered that English is the most utilized language among learners when utilizing Social media with a difficult level of utilization of primary language also and perhaps that is actually the motivation behind why the improvement is seen with Virtual Classroom learners and not with different learners. In the Virtual Classroom, the utilization of Social media is guided and led to talk just English and not different languages. In an inquiry intended for learners about the utilization of Social media to improve speaking most learners respected the idea and guaranteed its viability in learning. In like manner, learners accept that addressing local speakers is the best technique to profit by Social media notwithstanding executing them in research and correspondence.

Improving the speaking aptitude is a hard errand for unknown language students. It requires some technique and experience to create the language carefully and comprehend the expected implications of different speakers. As per numerous educators the most ideal approach to do that is; to empower some new systems inside or outside the study hall, since students don't utilize unknown language as often as possible in their day by day life outside the study hall (Alexiou \& Fotini, 2010; Namaziandost \& Nasri, 2019; Namaziandost, Rahimi Esfahani, Nasri, \& Mirshekaran, 2018). Our investigation has been centered around the adequacy of the utilization of Social media to improve EFL students speaking expertise. Along these lines, this investigation was made out of two sections (Theoretical, Practical part). The hypothetical part was a review on Social media, and the Speaking expertise, including the primary titles and sorts of every factor so as to give an unmistakable thought regarding every one and the connection between them. The down to earth some portion of this examination was an investigation so as to affirm the outcomes that have been acquired from the two learners and instructors' survey. The discoveries went connected at the hip with our speculation which stress that students will upgrade their speaking ability on the off chance that they utilize Social media in a proper manner.

The point of this examination was to research if there are any constructive outcomes or impact of Social media on EFL students speaking aptitude and decide to what degree Social media can be an aide for the educators to improve their courses of speaking exercises so as to urge their students to take an interest and improve their speaking ability, in light of the fact that most of learners need to utilize these guides in the study hall constantly so as to stay away from the exhausted investigation and make them spurred to take part in speaking exercises.

Most importantly, it merits clarifying that Social media can't be viewed uniquely as an engaging apparatus, they rather assume a primary job in the field of training and research, the nearness of Social media has changed a portion of the angles in the educator and the student jobs towards lucidity and adaptability and along these lines, teachers might anticipate actualize various instructional methods in order to stay aware of the mechanical headways.

The present segment is altogether committed to express some potential proposals and recommendations with respect to the work of Social media as a learning material to create learners ${ }^{e e}$ speaking capacities. EFL instructors then again need to allocate their students with assignments that help them convey and learn with each other. Moreover, innovation may be an advantageous way to satisfy such objective. The general discoveries of the present examination uncovered that the utilization of Social media is getting to be more extensive and more extensive among students just as instructors. The two of them utilize it in various fields to accomplish various objectives including instructive ones. Other than the way that Social media give time and abbreviate the separations, they make a loosening up setting for students to talk unreservedly and express their thoughts with no dread of shame or absence of certainty. In this manner, they help the students to conquer many speaking challenges and lift their speaking expertise.

To entirety up, this all-encompassing article has prompted reason that EFL educators ought to think about the convenience of Social media in advanced education without disregarding the commitment of the conventional strategies and methods. The reconciliation of Social media in EFL setting will give access to expand the language exercises and 
considerably more, to upgrade the learner's inspiration to master speaking which is accepted to be the fundamental factor that does not have the customary homeroom. Without a sorry excuse for uncertainty, the successive correspondence with local speakers around the globe by methods for Social media would improve the learner speaking just as listening aptitudes. In this way, it turned into a need to give innovation a considerable amount of significance in EFL setting.

\section{REFERENCES}

[1] Abram, C., \& Pearlman, L. (2010). Facebook For Dummies (2nd ed.). Indiana: Wiley Publishing, Inc.

[2] Akinola, O. T. (2015). social media as a weapon mass instruction in training library and information science. In A. Tella, Social Media Strategies for Dynamic Library Service Development (pp. 175-202). IGI Global.

[3] Al Musa, A. b. (2002). Using Computers in Education. Riyadh. Ima Mohamed BinSaud Islamic University.

[4] Al Musa, A. B., \& Al Mubarak, A. B. (2005). Electronic Education: Basics Applications. Riyadh: Data Net.

[5] Alexiou, A., \& Fotini, P. (2010). Enhancing self-regulated learning skills through the implementation of an e-portfolio tool. Procedia Social and Behavioral Sciences, 2(2), 3048-3054.

[6] Aloraini, S. (2012). The impact of using multimedia on students' academic achievement in the College of Education at King Saud University. Journal of King Saud University -Languages and Translation, 24(2), 75-82.

[7] Azadi, G., Biria, R., \& Nasri, M. (2018). Operationalising the Concept of Mediation in L2 Teacher Education. Journal of Language Teaching and Research, 9(1), 132-140.

[8] Aziz, S., Shamim, M., Aziz, M. F., \& Avais, P. (2013). The Impact of Texting/SMS Language on Academic Writing of Students- What do we need to panic about? Elixir International Journal, 55(2013),12884-12890.

[9] Baker, J., \& Westrup, H. (2003). Essential Speaking Skills: A Handbook for English Language Teachers. London: Continuum.

[10] Brown, D. H. (1994). Principles of Language Learning and Teaching. Englewood Cliffs: Prentice Hall Regent.

[11] Burns, A. \& Joyce, H. (1997). Focus on speaking. Sydney: National Center for English Language Teaching and Research. Retrieved July 27, 2019 fromhttp://www.cal.org/caela/esl_resources/digests/Speak.html.

[12] Bygate, M. (2002). Speaking. In R. Carter \& D. Nunan (Eds.), The Cambridge guide to teaching English to speakers of other languages (pp. 14-20). Cambridge: Cambridge University Press.

[13] Channey, A. L. (1998). Teaching Oral Communication in Grades K-8. Boston: Allyn \& Bacon.

[14] Dörnyei, Z. (2003). The psychology of the language learner: Individual differences in second language acquisition. Mahwah, NJ: Lawrence Erlbaum.

[15] Dörnyei, Z., \& Ushioda, E. (2011). Teaching and researching motivation (2nded.). Harlow: Longman.

[16] Eren, Ö. (2012). Students' Attitudes towards Using Social Networking in Foreign Language Classes: A Facebook Example. International Journal of Business and Social Science, 3(20), 288-294.

[17] Gibbins, T., \& Greenhow, C. (2016). Students' out of school writing practices in an educational Facebook application. In I. R. Association (Ed.), Social Media and Networking: Concepts, Methodologies, Tools and applications (pp. 1011-1027). Hershey, Pennsylvania, USA: IGI Global.

[18] Gutiérrez, D. (2005). Developing oral skills through communicative and interactive tasks. Profile Issues in Teachers Professional Development, 6(1), 2 - 10

[19] Haigh, p. (2010). Social Network Websites: Their Benefits and Risks. London: Optimus education e-books.

[20] Harmer, J. (1991). The practice of English language teaching. London: Longman.

[21] Hashemifardnia, A., Namaziandost, E., \& Rahimi Esfahani, F. (2018). The Effect of Using WhatsApp on Iranian EFL Learners' Vocabulary Learning. Journal of Applied Linguistics and Language Research, 5(3), 256-267.

[22] Hashemifardnia, A., Namaziandost, E., \& Sepehri, M. (2018). The effectiveness of giving grade, corrective feedback, and corrective feedback-plus-giving grade on grammatical accuracy. International Journal of Research Studies in Language Learning, 8 (1), 15-27.

[23] Hosseini, E. Z., Nasri, M., \& Afghari, A. (2017). Looking beyond teachers' classroom behavior: novice and experienced EFL teachers' practice of pedagogical Knowledge to Improve Learners' Motivational Strategies. Journal of Applied Linguistics and Language Research, 4(8), 183-200.

[24] Levy, M. (2009). Technology in use for second language learning. The Modern Language Journal, 93(1), 769782.

[25] Littlewood, W. (2007). Communicative Language Teaching. Cambridge: Cambridge University Press.

[26] Maney, K. (2009). "Next: an internet revolution in higher education." BloombergBusinessweek.http://www.businessweek.com/technology/content/sep2009/tc20090914_969227.htm. (July 20, 2019)

[27] Namaziandost E., \& Nasri, M. (2019). A meticulous look at Long's (1981) interaction hypothesis: does it have any effect on speaking skill? Journal of Applied Linguistics and Language Research, 6(2), 218-230.

[28] Namaziandost E., \& Nasri, M. (2019). The impact of social media on EFL learners' speaking skill: a survey study involving EFL teachers and students. Journal of Applied Linguistics and Language Research, 6(3), 199-215.

[29] Namaziandost E., \& Shafiee, S. (2018). Gender Differences in the Use of Lexical Hedges in Academic Spoken Language among Iranian EFL Learners: A Comparative Study. International Journal of Research in English Education, 3(4), 64-80.

[30] Namaziandost, E., \& Ahmadi, S. (2019). The Assessment of Oral Proficiency through Holistic and Analytic Techniques of Scoring: A Comparative Study. Applied Linguistics Research Journal, 3(2), 70-82.

[31] Namaziandost, E., Abdi Saray, A., \& Rahimi Esfahani, F. (2018). The effect of writing practice on improving speaking skill among pre-intermediate EFL learners. Theory and Practice in Language Studies, 8(1), 1690-1697. doi: http://dx.doi.org/10.17507/tpls.0812.16.

[32] Namaziandost, E., Abedi, P., \& Nasri, M. (2019). The Role of Gender in the Accuracy and Fluency of Iranian Upperintermediate EFL Learners' L2 Oral Productions. Journal of Applied Linguistics and Language Research, 6(3), 110-123. 
[33] Namaziandost, E., Nasri, M., \& Rahimi Esfahani, F. (2019). Pedagogical Efficacy of Experience-Based Learning (EBL) Strategies for Improving the Speaking Fluency of Upper-intermediate Male and Female Iranian EFL Students. International Journal of Research in English Education, 4(2), 29-41.

[34] Namaziandost, E., Rahimi Esfahani, F., \& Ahmadi, S. (2019). Varying levels of difficulty in L2 reading materials in the EFL classroom: Impact on comprehension and motivation. Cogent Education, 6, 1-9. https://doi.org/10.1080/2331186X.2019.1615740.

[35] Namaziandost, E., Rahimi Esfahani, F., Nasri, M., \& Mirshekaran, R. (2018). The Effect of Gallery Walk Technique on Preintermediate EFL Learners' Speaking Skill. Language Teaching Research Quarterly, 8, 1-15.

[36] Namaziandost, E., Saberi Dehkordi, E., \& Shafiee, S. (2019). Comparing the effectiveness of input-based and output-based activities on productive knowledge of vocabulary among pre-intermediate EFL learners. Asian-Pacific Journal of Second and Foreign Language Education, 4(2), 1-14 https://doi.org/10.1186/s40862-019-0065-7.

[37] Namaziandost, E., Sabzevari, A., \& Hashemifardnia, A. (2018). The effect of cultural materials on listening comprehension among Iranian upper-intermediate EFL learners: In reference to gender. Cogent Education,5(1), 1-27. https://doi.org/10.1080/2331186X.2018.1560601.

[38] Nasri, M. \& Biria, R. (2017). Integrating multiple and focused strategies for improving reading comprehension and 12 lexical development of Iranian intermediate EFL learners. International Journal of Applied Linguistics \& English Literature, 6(1), 311-321.

[39] Nasri, M., Biria, R., \& Karimi, M. (2018). Projecting Gender Identity in Argumentative Written Discourse. International Journal of Applied Linguistics \& English Literature, 7(3), 201-205.

[40] Paliktzoglou, V., \& Suhonen, J. (2014). Facebook as an assisted learning tool in problem-based learning: The Bahrain case International Journal of Social Media and Interactive Learning Environments, 2(1), 85-100.

[41] Pichette, F. (2009). Second Language Anxiety and Distance Language Learning. Foreign Language Annals, 42(1), 77-93.

[42] Thornbury, S. (2005). How to teach speaking. U.K.: Pearson.

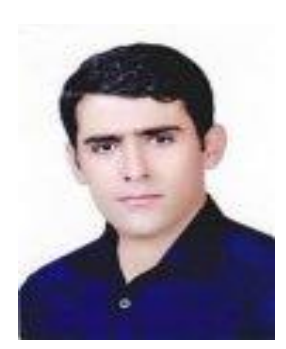

Ehsan Namaziandost was born in Shiraz Province of Iran in 1985. He holds an MA degree in TEFL from Islamic Azad University of Ahvaz. Now, he is Ph.D. candidate of TEFL at Islamic Azad University, Shahrekord, Iran. His main interests of research are second language acquisition, EFL teaching and testing, teaching language skills, and language learning strategies. His research papers and articles have been published by different international journals.

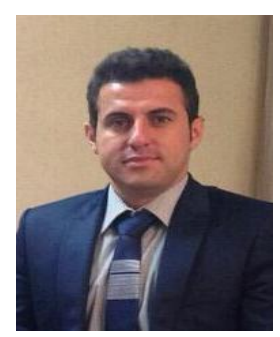

Mehdi Nasri was born in Isfahan, Iran. He holds a master's degree in TEFL from Islamic Azad University of Isfahan (Khorasgan). He is currently studying PhD in TEFL at Islamic Azad University of Shahrekord, Iran. He published some articles in different international journals and presented some ones in national conferences in Iran. His areas of interest are second language vocabulary learning and teaching, pragmatics, and reading comprehension.

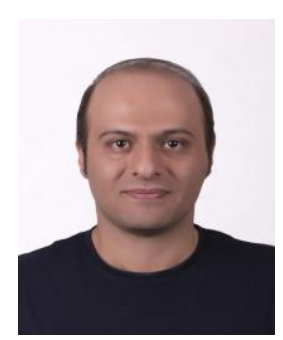

Mohanmad Hossein Keshmirshekan was born in Yazd Province of Iran in 1981. He holds an MA degree in TEFL from University of Yazd. His main interests of research are second language acquisition, EFL teaching, sociolinguistics, contrastive analysis, and language learning strategies. His research papers have been published by various international journals. 